\title{
Promoting and Capitalizing on the Vestiges from Sarmizegetusa Regia by Modern Multimedia Methods Călin NEAMȚU, Vitalie BÂRCĂ, Zsolt BUNA
}

\begin{abstract}
Sarmizegetusa Regia was included, together with the other five Dacian fortresses, on the List of UNESCO World Heritage Sites in 1999. They are a unique synthesis of external cultural influences and local traditions in terms of building techniques and overall, in the ancient military architecture, representing the grand expression of the civilisation of the Dacian Kingdom. These fortresses are the accurate expression of the exceptional development level of the Dacian civilisation, Sarmizegetusa Regia lying at the forefront of this fortified complex, epitomizing the evolution phenomenon from fortified centres to proto-urban agglomerations. As such, promoting these monuments and the numerous artefacts discovered by modern methods and techniques should become a priority. This paper presents a series of last generation applications and equipment that may be successfully used in promoting cultural heritage. Case studies include scanned artefacts and 3D reconstructions of the monuments in the site of Sarmizegetusa Regia, a monument on the UNESCO List of World Heritage Sites together with the other five Dacian fortresses (Bănița, Costești-Blidaru, Costești-Cetățuie, Piatra Roșie and Căpâlna). We present here the results obtained following the use of several hardware tracking systems, augmented virtual reality applications and haptic devices. One of the important aspects, when attempting to make enhanced on-line use of heritage good is the extent to which it is accessible and reusable by various categories of users, either specialists or the general public. Digitalizing a good in the cultural heritage is the first step for ensuring the broad access via the on-line medium, the quality of this process ensuring the electronic format artefact legitimacy and credibility, which means that it should be an electronic duplicate truthful to the real artefact. This way, they may be digitally preserved and used in various manners. Digitalizing artefacts and the digital reconstruction of houses, appurtenances, workshops, temples and fortifications and the set-up of virtual tours ensure incursions in the daily life as resulting from the archaeological finds yielded over several decades. This process results in quick promoting of this cultural heritage and its international capitalizing. All this completed by a database in the form of an open web platform to manage the 3D models, which may be later completed by other scanned 3D models, is the way to proceed for as many as possible monuments and artefacts.
\end{abstract}

Keywords: Sarmizegetusa Regia, cultural heritage digitalizing, terrestrial laser scanning, virtual reality, augmented reality, on-line database, cultural heritage dissemination. 
It is well-known that human actions and activities imprint the evolution of society. Human actions leave traces that also represent the features of the society within which human communities lived in the course of time, but also their living conditions and lifestyle. Social, economic but also political shifts leave significant traces, often defining ones, on human values, daily life, natural landscapes, archaeological monuments and sites. The evolution of society and constant changes of the world we are living also impact the cultural heritage, whose state and preservation are an important indication of the development state of the society and its education and cultural level (Bârcă 2019: 109). Therefore, promoting the artefacts and monuments, regardless of their identity or confessional affiliation, by modern techniques and methods should become an international priority ${ }^{1}$.

This study aims at presenting how a series of methods and technologies, associated with the virtual environment, have been applied to promote the artefacts and the monuments of Sarmizegetusa Regia.

Sarmizegetusa Regia ${ }^{2}$ (Figures 2-3), the capital of the Dacian Kingdom, together with the fortresses of Bănița, Costești-Blidaru, Costești-Cetățuie, Piatra Roșie and Căpâlna ${ }^{3}$, included among the UNESCO world heritage sites in 1999 (UNESCO 1999), count among the best known ancient monuments of Romania. They are a unique synthesis of external cultural influence and local tradition in terms of building techniques and overall, of the ancient military architecture $^{4}$, being the grand expression of the Dacian Kingdom's civilisation.

1 The implementation of the UN resolutions regarding recognition of the cultural heritage as an important factor of sustainable development, of social inclusion and integration, as well as the protection and promotion of the universal cultural heritage and its importance for the evolution of human society should be a worldwide priority. Also, the cultural heritage should become of the basic pillars in the construction of a society, while the cultural heritage, by the possibility of all to have access to the resulting benefits, to contribute to the sustainable development of the society. In fact, it is only this way that the cultural heritage, regardless its identity or confessional affiliation, will represent indeed the inheritance left by previous generations, especially since it was created by peolpe for people (Bârcă 2019: 109-110).

2 On the list of UNESCO World Heritage Sites, Sarmizegetusa Regia (Orăștioara de Sus commune, Grădiștea de Munte village, Hunedoara district) has the identification code no. 906-001, coordinates N 453723.00 and E 2318 43.00. On the List of Historical Monuments (LHM) of Romanian its code is as follows HD-I-s-A-03190.

3 For the history of research of these fortifications see Daicoviciu, Ferenczi and Glodariu 1989: 121-173; Gheorghiu 2005: 17-23; Mateescu 2017: 357-362.

4 The six fortresses, alike others within or outside this area, lay on high relief forms, in barely accessible positions. The peculiarities of the land were enhanced so they could benefit from 


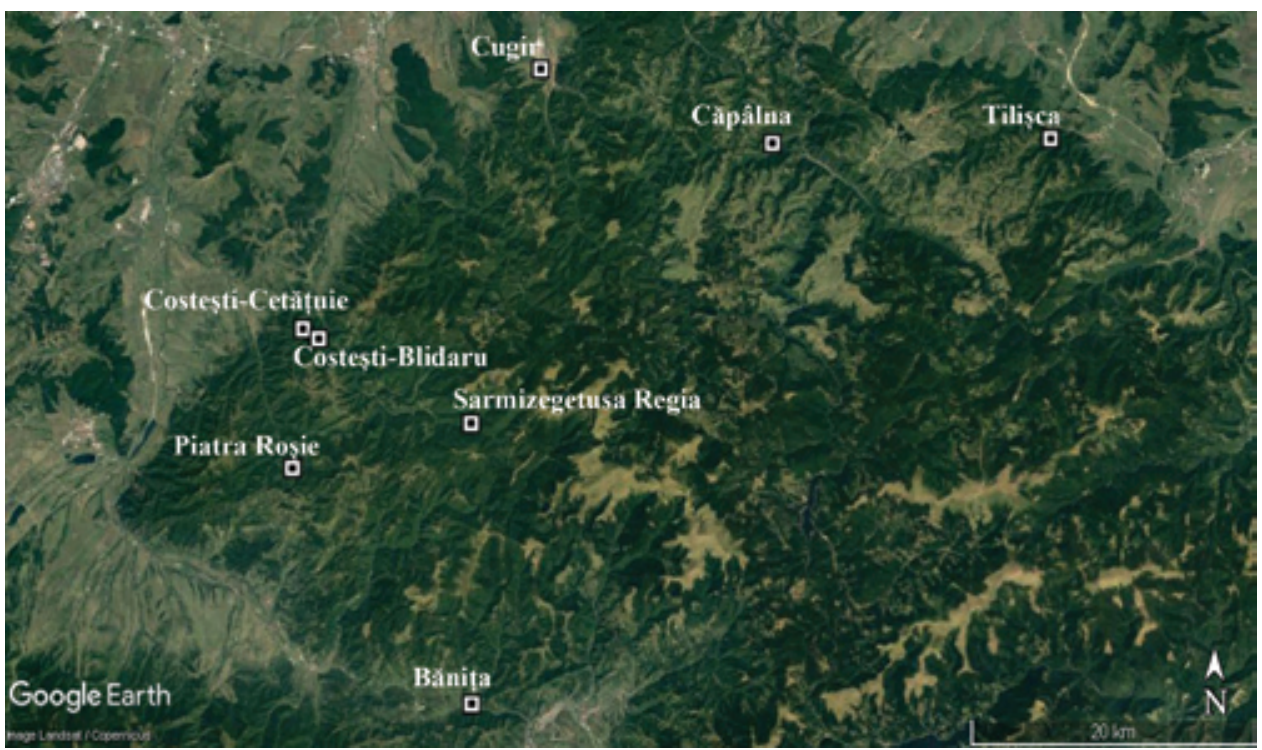

Figure 1. Map with the location of the Dacian fortresses included among the UNESCO World Heritage sites

The six fortresses delimit an area of ca. $150 \mathrm{~km}^{2}$ which, for almost two centuries, was the most extensively inhabited area of Dacia (Mateescu and Pupeză 2016: 221) (Figure 1).

All these fortresses date to the $1^{\text {st }}$ century BC-early $2^{\text {nd }}$ century $\mathrm{AD}$ and form, beside a few other, a complex known under the generic name of Cetățile dacice din Munții Orăștiei (the Dacian fortresses of the Orăștiei Mountains).

The Grădiște Hill, where the ruins of Sarmizegetusa Regia lay, is located by the south-eastern edge of Grădiște grassland, at approximately $17 \mathrm{~km}$ south the village of Costești and $7 \mathrm{~km}$ from the central area of village Grădiștea de Munte, past the interflow of Valea Albă and Valea Godeanului streams and is a foot of Muncel (Daicoviciu, Ferenczi and Glodariu 1989: 193-195; Gheorghiu 2005: 62). Recent survey measurements indicate that on its main axis, along the central hill crest, the site of Sarmizegetusa Regia extends on a length of 4.5 kilometres and comprises more than 260 manmade terraces, set up in antiquity, but also that it covers a surface of almost 400 flat land hectares ${ }^{5}$. Sarmizegetusa Regia, the main political, religious, economic and military

excellent natural defence, some being erected on high cliffs, almost vertical. For the military architecture see Glodariu 1983; Daicoviciu, Ferenczi and Glodariu 1989: 69 sqq.; Mateescu and Pupeză 2016: 221-249.

5 See Florea 2017: 363, pl.113/1-2. I thank this way also my friend Dr Răzvan Mateescu, member of the research team of Sarmizegetusa Regia, for kindly offering this information, yet also much other related to the archaeological investigations and protection of this monument. 
centre of the Dacian world for over one century and a half, is the largest known settlement in the Dacian space. It is formed of three distinct parts: the fortress, the sacred area and the "quarters" with civil constructions, the latter lying both to the east and the west of the first two,

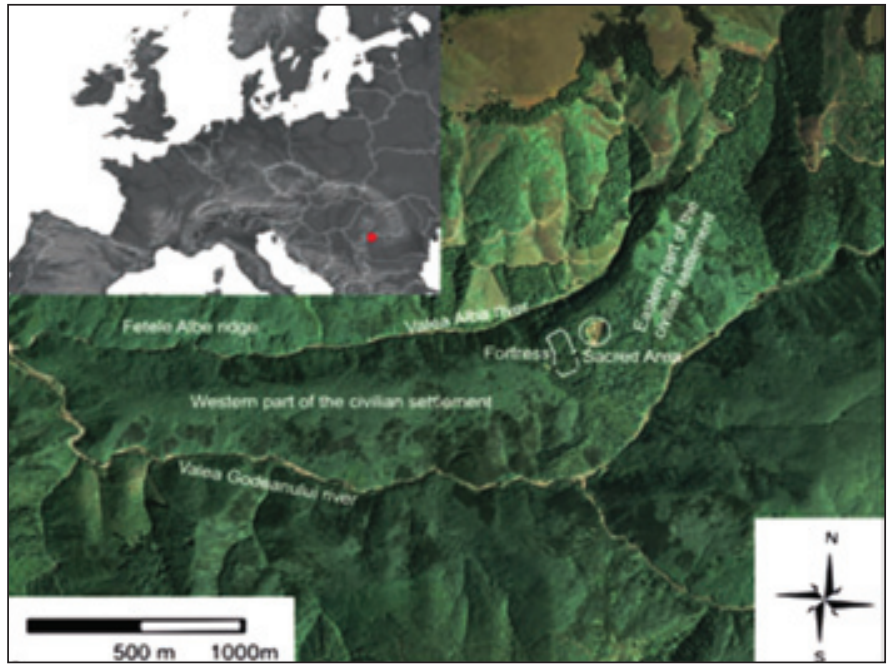

Figure 2. Sarmizegetusa Regia. Satellite map (after G. Florea, 2017) which were central to the settlement (Gheorghiu 2005: 62). All civil, military or cult constructions are located on manmade terraces, those of the sacred area being supported and protected by strong walls built in the murus Dacicus technique, of Hellenistic influence. In antiquity, some of these supporting walls stood up to $12 \mathrm{~m}$ high on certain portions (cf. Mateescu 2016: 195). The large terraces covered surfaces of thousands of square meters, almost half a hectare, the largest $150 \mathrm{~m}$ long and ca. $80 \mathrm{~m}$ wide. For their construction, hundreds of thousands of cubic meters of earth and rock were excavated, levelled and stabilised (Gheorghiu 2005: 63).

The fortress was built in the single spot in the area with adequate configuration, namely around the hillock with a maximum height of 1042 $\mathrm{m}$, dominating both the western "quarters" of the capital in the front and the sacred area, lying at a ca. $1000 \mathrm{~m}^{6}$ altitude. The fortress surrounded the hillock alongside the land configuration (Gheorghiu 2005: 63).

After the war of 101-102, the Dacians were forced, according to the peace terms closed with the Romans, to dismantle part of the enclosure wall of the fortress. Its reconstruction by the Dacians took place around the outbreak of the second Dacian war, after the departure of the Roman military units. The Dacian fortress, with an estimated surface of ca. $10.000 \mathrm{~m}^{2}$, was almost completely damaged by the large scale destructions and land development works during the wars and just after their conclusion?

${ }^{6}$ On terrace X, the height is of $998 \mathrm{~m}$, while on terrace IX of $1000 \mathrm{~m}$. Amicable information by Dr Răzvan Mateescu.

7 Today only a small portion is still visible, it too adjusted and modified by the Romans after their settling of Sarmizegetusa Regia. 

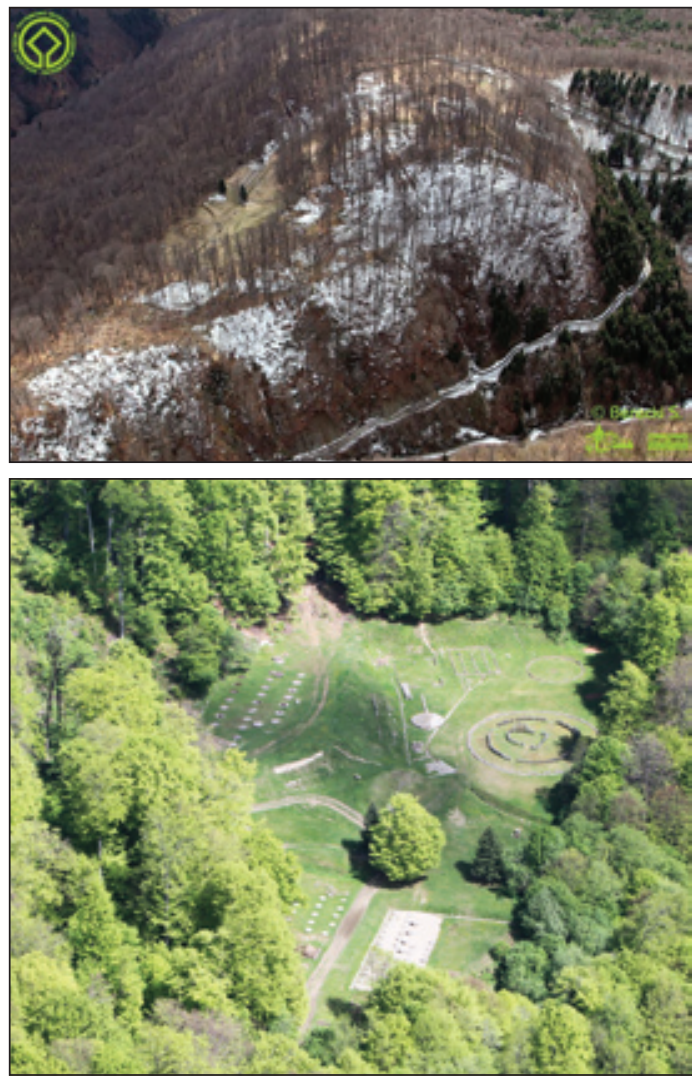

Figure 3. General aerial view of the Sarmizegetusa Regia fortress (top) (photo Sándor Berecki, 2018); aerial view of the sacred area (bottom) (after R. Mateescu, 2012)
Today's fortification was built by the Romans by early 2 nd century AD after the conquest of Dacia. Its walls, made especially of limestone blocks, enclose a surface of ca. $30.000 \mathrm{~m}^{2}$. In some of the walls, portions of architectonical andesite pieces, originating in the Dacian religious buildings of the sacred area, were incorporated ${ }^{8}$.

The civil construction of Sarmizegetusa Regia consisted of houses, barns and sheds, many workshops, drainage channels, water pipes, paved roads, stairs (Gheorghiu 2005: 64, 136, 137; Daicoviciu et alii 1961: 309-310. Glodariu 1983; Suciu 2000: 3647; Bodó 2016), etc. The houses were rectangular (with two, three rooms), polygonal or circular. On the terraces of the civil "quarters" there commonly lay one house and its extension, the latter being usually a barn made entirely of timber (Gheorghiu 2005: 64).

On the current path of the wall, at $38 \mathrm{~m}$ from the southern gate towards that in the west, below the wall was discovered a Roman metalworking workshop built after the land was levelled, which also lay on the top of a Dacian coin mint burnt in AD 106 (Glodariu, Iaroslavschi and Rusu 1992: 57-68). Besides the fourcoin stamps used to mint coins copying Roman denarii (Republican denarius from 126 BC, Republican denarius from 86 BC, denarius of Emperor Tiberius), iron and bronze slag was also discovered in the workshop, but also a lead piece indicative that other objects must have been very likely produced there.

The civil settlement and sacred area were provided with drinking water storage and supply systems via fired clay pipes (cf. Gheorghiu and Pupeză 2016), but also with rainfall drainage systems. On the latter, drainage channels

8 In various points within and immediate vicinity, traces of barracks and certain Roman buildings, like the baths, were discovered. 
from the sacred area are visible on the stone. A timber cistern, supplied still through a fired clay pipe, was discovered south the fortress walls (Gheorghiu 1996; 2005: 64. See also Gheorghiu 1997-1998).

The religious architecture counts among the peculiarities of the Dacian inhabitancy of the Orăștiei Mountains, while the buildings from Sarmizegetusa Regia represent the peak of the religious architecture in Dacia (Mateescu 2016: 193).

The temples of Sarmizegetusa lay on two manmade terraces (terrace $\mathrm{X}$ and terrace XI), supported by the walls of massive limestone blocks, which stood even to $12 \mathrm{~m}$ high on certain portions. The terraces are situated east the fortress and form an impressive sacred area, where, at some point, seven temples and the andesite altar ${ }^{9}$ functioned concurrently. Besides temples, they also discovered systems for water supply and discharge (the stone spillway on terrace XI and pipes of terracotta tubes). The surviving elements of the sacred area (the plinths, drums, limestone and andesite pilasters from temple structures etc.), but also the fortification wall erected by the Romans, are indicative of grand religious architecture. The connection between the sacred area and the fortification was made by a road paved with limestone slabs.

Should we agree that the fortifications' system of Şureanu Mountains was built to protect and control access to Sarmizegetusa Regia, then it inevitably represents, as well noted, the implementation of design of centre-periphery type territorial set up (Florea 2011: 161).

Last but not least, the Dacian highly developed iron metallurgy of the period must be mentioned here, especially in the capital, where many ironworking workshops were found (Glodariu 1975; Glodariu and Iaroslavschi 1979: 22, 39; Iaroslavschi 1997: 11-25, 48-95; 2004: 58-59; Gheorghiu 2005; 147-151; Iaroslavschi and Mateescu 2016: 63-66), while the discovered iron quantity in tools ${ }^{10}$ and lumps only at Sarmizegetusa Regia exceeds the quantity identified in the rest of Europe outside the Roman empire (Glodariu and Iaroslavschi 1979: 150).

The finds evidence that in the capital area a true siderurgical industry developed, the numerous workshops supplied with iron mined in the area producing enough to satisfy the growing needs of the local settlements, but also of those located somewhat farther (Glodariu and Iaroslavschi 1979: 59; Iaroslavschi and Mateescu 2016: 63-66).

9 For the temples of Sarmizegetusa Regia, but also the rest of Dacia see Antonescu 1984; Crișan 1986; 1993; 2016; Gheorghiu 2005: 202-208; Rusu-Pescaru 2005; Florea 2011; Mateescu 2012.

${ }^{10}$ For the many classes of artefacts made of iron see Glodariu and Iaroslavschi 1979: 43-123. 
A special place is held by stone mining and working (Cf. Iaroslavschi 1997: 26-42; Gheorghiu 2005: 172-174), especially if we consider the impressive military and religious buildings of Sarmizegetusa Regia, and those in the other five fortresses that form this fortified complex. Various types of rocks were used for their constructions, some (limestone and andesite) being mined in quarries located at considerable distances, others in the construction area (mica-schist mainly) (Glodariu 1983: 98).

To these add glassworking (Iaroslavschi 1997: 96-102; 1981: 166-173; Gheorghiu 2005; 174-175), timberwork ${ }^{11}$, precious metals working ${ }^{12}$ and pottery are added ${ }^{13}$. A special class of Dacian pottery, discovered mainly in the fortresses and settlements from the Orăștie Mountains, is represented by painted pottery. It was produced under influences arriving from the Mediterranean world, with dominating geometric pattern engobe painting, of Hellenistic origin, dominating (Florea 1998: 233; Florea and Cristescu 2016: 143-145). In the 1st century $\mathrm{AD}$, emerges the figurative style specific to the pottery centre from the Orăștiei Mountains emerges, a novelty in the ensemble of painted pottery production and late Dacian artwork and a decorative innovation born in a workshop within the Sarmizegetusa Regia milieu (Florea 1998: 236-237). Only at Sarmizegetusa Regia a paining genre inspired by the surrounding nature and the local mythological background, also emerges (Florea 1998: 237).

Last but not least, at Sarmizegetusa Regia were discovered over time thousands of pieces. Besides covered over time, already mentioned artefact types (ironwork, timber and woodwork tools), we mention here jeweller's tools, farming tools, household objects, weapons, decorative pieces, many pottery wares, jewellery and dress items, coins etc. (Cf. Gheorghiu 2005; Neamțu et alii 2016).

All the above furthermore evidence that the fortifications' system of the Orăștiei Mountains is the specific expression of the exceptional development

${ }^{11}$ Timber was used in building houses, their extensions, cisterns, but also for furniture. It was also used in the sacrd architecture (in the making of the temples' superstructures), but also in that military one (palisades, transversal girders connecting the two worked stone wall faces etc.). It must be mentioned that in the Şureanu Mountains area, at Sarmizegetusa Regia and Muchia Chișetoarei, part of the cisterns' timber structure survived - larch, respectively durmast wood (Cf. Iaroslavschi 1997: 102-108; Gheorghiu 2005: 151-154; Iaroslavschi and Mateescu 2016: 66-68).

${ }^{12}$ Bronze and precious metal workshops were operational at Ardeu, Bănița, Căpâlna, CosteștiCetățuie, Piatra Craivii, Piatra Roșie but also at Sarmizegetusa Regia, as shown by archaeological finds (Cf. Bodó and Ferencz 2004: 154; Rustoiu 1996: 58; Glodariu and Moga 1989: 98-99, 103, 115;. Florea 1992: 39-47; Moga 1979: 513-518; Moga and Rustoiu 1997: 57-63; Daicoviciu C. 1954: 78, 81, pl. XIV/6-7; Daicoviciu C. et alii 1955: 208-209; Gheorghiu 2005: 155). See also Iaroslavshi and Mateescu 2016: 68-69; Florea et alii 2015; Mateescu 2010.

${ }^{13}$ Gheorghiu 2005: 138-146, with complete bibliography; Florea and Cristescu 2016: 142-145. 
level of the Dacian civilisation throughout the 1st century BC - early 2nd century AD, with Sarmizegetusa Regia at its forefront, an example of the evolution phenomenon from fortified centres to proto-urban agglomerations (oppida), which characterised the end of the Iron Age in Europe ${ }^{14}$. Based on archaeological finds, the scale of the site has resulted, supplied by LIDAR scanning and survey measurements, as well as the presence of several principles of classical urbanism at an urban settlement in Sarmizegetusa's case, as recently maintained (Bârcă 2019: 81).

Nowadays technology surrounds us in every aspect of life, it is used for either productivity, communication or entertainment. Thus, the information and communication technology (ICT) helps improve living standards and helps users to get information faster and in an intuitive way. As Rey and Casado-Neira said back in 2013, is that "the use of ICT, as part of the visiting experience, does not seem to have reached a degree of maturity and to be of significant relevance for the visitors, but accepted within a traditional conception of what a museum is". However, since then the growth of technology (in the area of smartphones, tablets, smart devices, smart TV) has been rapidly increasing, the user pool of such devices has also been significantly increasing, and people are less afraid to interact with such devices. Thus, ICT having more success in our days in museums, especially for the younger generations, who are more attracted to smart gadgets and are not afraid to discover new things by interacting with them. In this regard, many interactive systems have been developed over time, some of them especially for museum exhibitions. These technological innovations (in the field of mobile smart devices, multi-touch screens, augmented reality and virtual reality applications) and the use of these technologies have been subject of many discussions amongst researchers.

Most published research works are project-oriented to achieve best practices regarding visiting experience enhancement for visitors in museum exhibitions. In this context, some of the most used ICT systems in museums are the following: multi-touch tabletops, haptic devices, augmented reality applications, virtual reality applications and tracking systems. Sometimes two or more systems are used together to create an immersive experience. Tabletop systems have been developed to be used in museum spaces for browsing image databases (Ciocca, Olivo and Schettini 2012; Comes 2018: 267-270), for information browsing/learning (Hornecker 2008), or learning while 2006). This technology enables users to interact with applications using touch gestures and to handle digital contents (images, videos, digital

${ }^{14}$ See to this effect Florea 2011. 
objects). More than one visitor can use multi-touch tabletops at a time; therefore, it can be more engaging for the visitors. Haptic devices recreate the sense of touch by applying forces, vibrations, or motions to the user. A midair haptic device was successfully used by Ablart (Vi et alii 2017) to enhance the visitors' experience in an art museum. Augmented reality is an interactive experience of a real-world environment where the objects that reside in the real world are "augmented" by computer-generated perceptual information, usually in form of text, images or video, around the real object. Augmented reality systems were used to create dynamic storytelling (Keil et alii 2013), mobile augmented guide (Gimeno et alii 2017), enhance museum experience and purchase intentions ( $\mathrm{He}, \mathrm{Wu}$ and $\mathrm{Li} 2018$ ) or to interact with digital contents easily and naturally, similar to interacting with real-world objects (Kyriakou and Hermon 2019). Virtual reality, on the other hand, immerses the users completely in a virtual world, where they can explore all sorts of digital contents. Carrozzino (Carrozzino and Bergamasco 2010) created a very thorough classification of virtual reality systems (on the interaction and immersion axes) that were used in museums and pointed out the pros and cons of each system. There are systems designed for multi-user or single-user experiences, the latter being more interactive and immersive with the visitors. The evolution of consumer technologies in this field allows museums to adapt commercial devices with accessible costs. Moreover, these devices are familiar to a wider range of audience, increasing the chance that the visitors will interact with these devices in the exhibitions. According to the Virtual Reality Society (VRS 2017). "Virtual reality is the term used to describe a three-dimensional, computer-generated environment which can be explored and interacted with by a person. That person becomes part of this virtual world or is immersed within this environment and whilst there, can manipulate objects or perform a series of actions".

Experimenting with several technologies currently associated with the virtual environment for a series of artefacts and monuments from Sarmizegetusa Regia was accomplished within project "Când viața cotidiană antică devine patrimoniu UNESCO. Scanarea, restaurarea digitală și contextualizarea artefactelor dacice din Munții Orăștiei"1s ("When the ancient daily life becomes UNESCO heritage. Scanning, digital restoration and contextualizing of the Dacian artefacts from Orăștiei Mountains"). The project was funded through the

\footnotetext{
${ }^{15}$ Project drafted and implemented by the Technical University of Cluj-Napoca in partnership with the National Museum of Transylvanian History, Babeș-Bolyai University and the Museum of Dacian and Roman Civilisations in Deva.
} 
Financial Mechanism SEE 2009-2014 project line: PA16/RO12 Preserving and revitalizing the cultural and natural heritage ${ }^{16}$.

The project attempted to make an incursion in the Dacian daily life as it results from the archaeological finds of the almost 100 years of systematic research in the Dacian fortresses of Orăștiei Mountains. Thus, more than 500 representative artefacts of the Dacian heritage were digitalized for their promotion at the international level, together with the conversion of more than 500 digitalized artefacts discovered in the Dacian sites included among the UNESCO World Heritage sites (Figure 4). A database in the form of an open web platform was established for managing $3 \mathrm{D}$ models and metadata following the Europeana portal ${ }^{17}$, which may be completed later with the other 3D scanned models. Certain houses and their extensions, workshops, Dacian temples and fortifications from the Orăștiei Mountains were digitally reconstructed, and a virtual tour of the museum available online was created. Also, a large catalogue of the real and virtual pieces was published, as well as restorations of the Dacian pieces, constructions and fortresses, visible in normal or anaglyph formats (cf. DACIT 2019).

Still within the project were set up two multimedia exhibition areas, one with the National Museum of Transylvanian History in Cluj-Napoca and another with the Museum of Dacian and Roman Civilisations of Deva, which house the two mixed exhibitions: real/
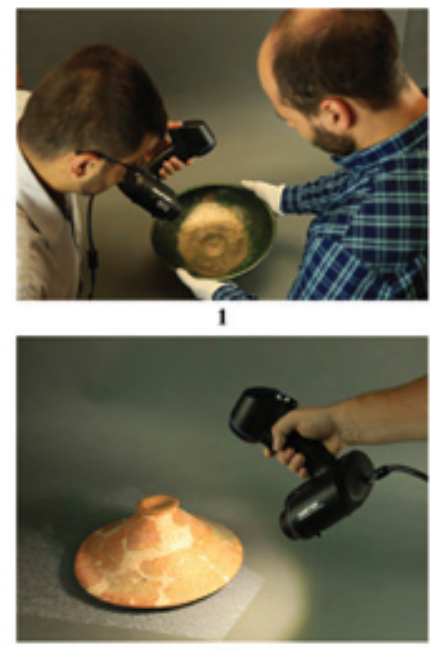

2

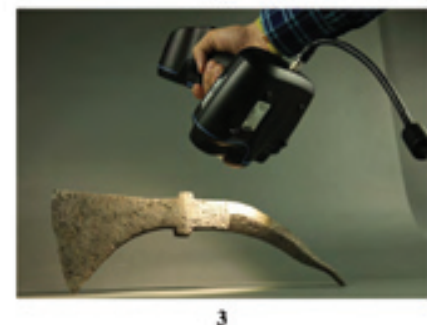

3

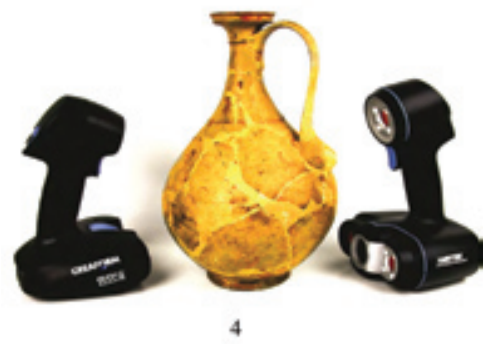

Figure 4. Aspects from during the scanning of the artefacts (1-3); type of devices used to scan the artefacts (4) (after C. Neamțu, G. Florea, G. Gheorghiu and C. Bodó, 2016) virtual, Incursiuni dacice in mediul virtual. They provide the visitors with the opportunity to interact with the virtual environment represented by digitalized artefacts and monuments restored

\footnotetext{
${ }^{16}$ Project funded by a grant offered by Island, Liechtenstein and Norway.

${ }^{17}$ Europeana.eu is an internet portal operating as an interface to millions of books, paintings, films, museum objects and archive records etc. digitalized throughout Europe.
} 


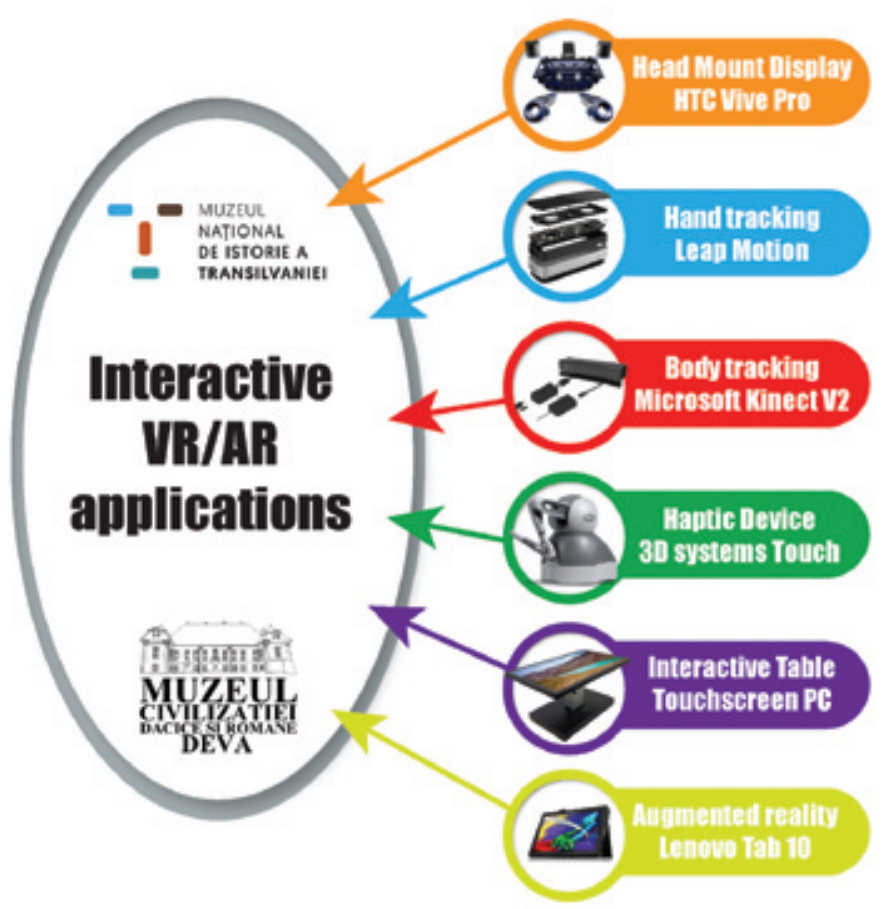

Figure 5. Different levels of complexity for hardware associated with VR

virtually ${ }^{18}$, thus the user can explore and handle several parts of a virtual environment (Figure 5).

Given the nature of museum activities and public type at the time when a presentation multimedia technology is chosen, one must consider two very important aspects: the reliability of the software-hardware solution and usability of the solution.

In Figure 5 the augmented reality type applications are believed the most reliable and which provide the highest usability degree, as these applications may be provided to the users and users may use them on their own devices, in this case, the usability is mainly given by the application ergonomics. At the opposite pole lies HMD (Head Mounted Display), which functions in a highly sophisticated hardware-software configuration, which entails increased focus when handling and constant assistance on the part of the museum employees for the user.

\footnotetext{
${ }^{18}$ In each of the two spaces were set up the following equipments: multimedia 3D professional projector ( $1 \mathrm{pc}$.), multimedia 3D projector $(2 \mathrm{pcs}$.$) , haptic device (2$ pcs. $)$, interactive table (1 pc.), Microsoft kinect (3 pcs.), display 3D Smart TV (3 pcs.), monitor 3D 24“ (6 pcs.), 3D glasses, blinds system for exhibition halls, exhibition cases, audio system, exhibition lighting system, theft-proof system. For further information on the project and its remarkable results see the project website: dacit.utcluj.ro.
} 
All virtual and augmented reality applications used in museum settings should use as faithful as possible digitalised models (Neamțu, Comes and Popescu 2016) that would render as realistically as possible the shape and texture of the real artefacts and monuments.

Digitalizing is the most important operation which prepares objects and settings as well as the information to be used in AR/VR applications. Thus, it is most often required the digitalizing of primary information regarding the monument/artefact, which is commonly presented only in classical paperback format. Artefacts may be digitalized by using 3D scanners which concurrently

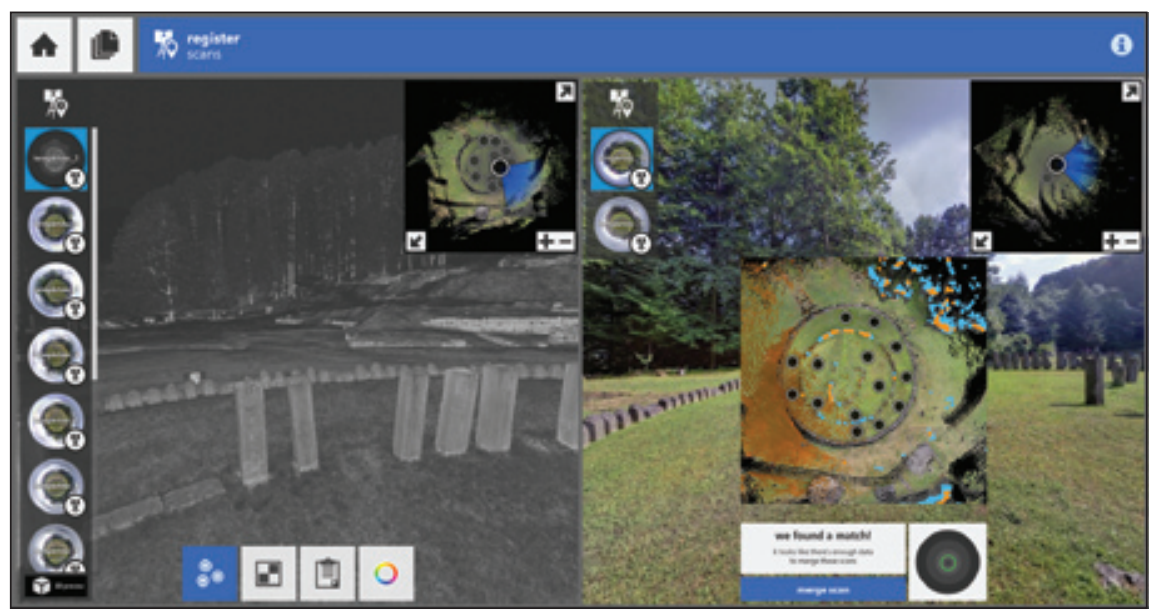

Figure 6. Terrestrial Laser Scanning of TMC

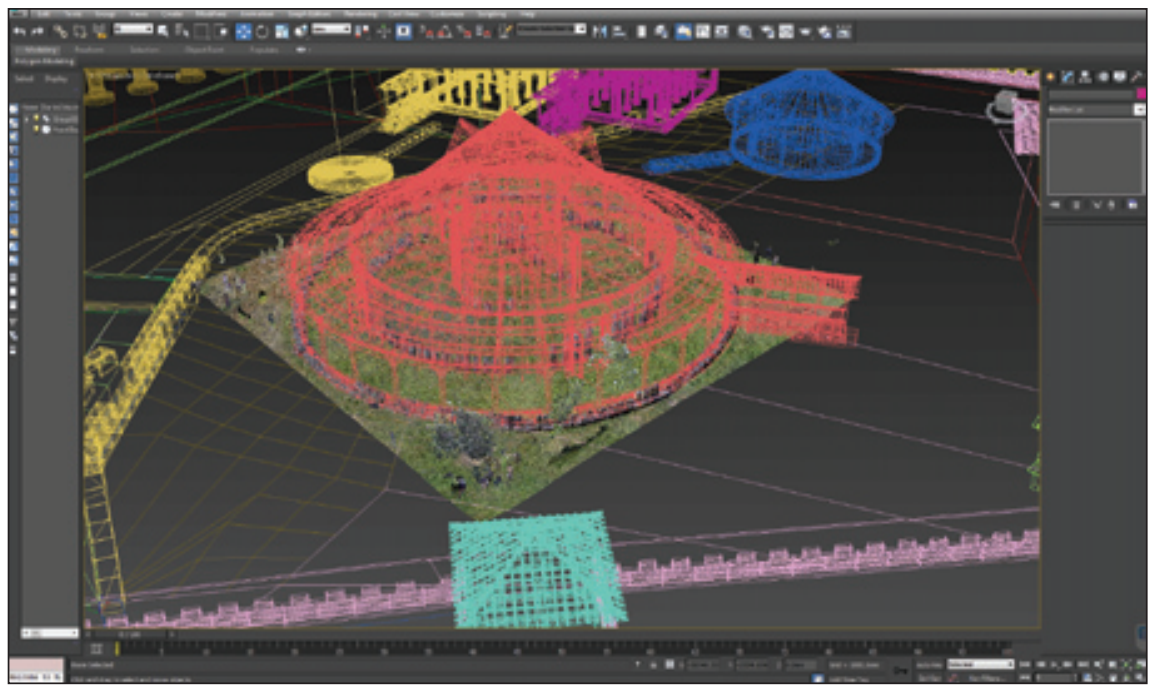

Figure 7. Reconstruction of the large circular temple by terrestrial laser scanning and 3DSMax 


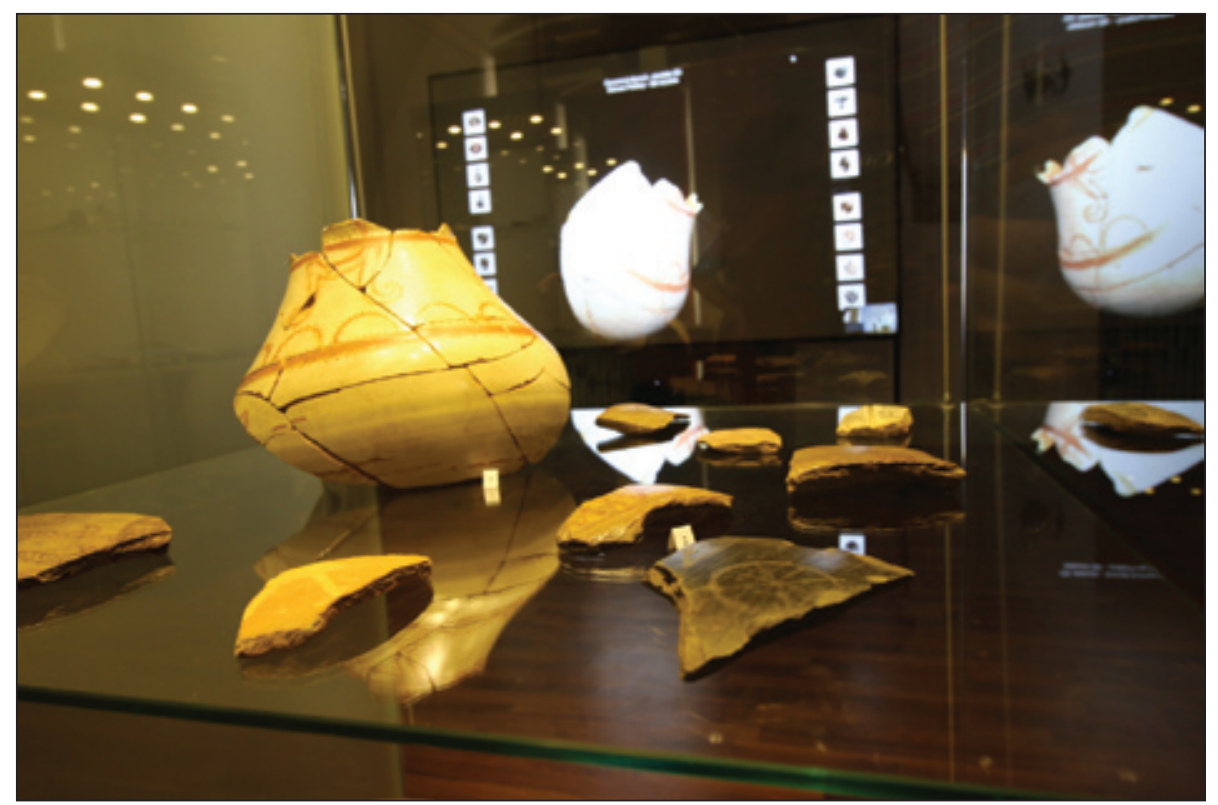

Figure 8. Location of the artefacts within the exhibition

acquire shape and texture and allow obtaining a highly truthful digital artefact, both dimensionally ( up to $50 \mu \mathrm{m}$ ) and texturally.

By using the terrestrial laser scanning (Figure 6) a virtual replica of the real model of a monument may be obtained, after which, by using several 3D modelling solutions, a monument may be restored starting from real field data (Figure 7).

After their scanning and reconstruction, the artefacts may be promoted to the broad audiences via various interactive multimedia means, like virtual reality, augmented or mixed reality. The first step in making some interactive applications designed for museum exhibitions is the design of the setting and identification of the presentation methods.

For the cultural heritage of Sarmizegetusa Regia, an adjustable setting was designed which allows presentation by using state of the art virtual and augmented reality technologies in presenting both the artefacts as well as the $3 \mathrm{D}$ reconstruction of the archaeological site.

In presenting the Dacian artefacts discovered in the Orăștiei Mountains, two sensor types were used, which enable interaction with 3D models: a fullbody tracking sensor (Microsoft Kinect) and a hand tracking sensor (Leap Motion). Applications developed for these two sensor types allow the user to handle and virtually check a virtual artefact. The setting was thusly designed so that these applications be located just nearby the cases in which the real artefacts are exhibited (Figure 8). 


\section{Head Mount display HTC Vive Pro VR application}

Virtual reality is becoming an increasingly important tool used for cultural heritage dissemination and popularization. Virtual reality applications have become popular within the past years and multiple exhibition areas have created custom made applications to better showcase their artefacts. Most exhibitions are currently presenting virtual reconstructions that contain mostly static objects with the possibility to interact with the objects by picking them up in virtual reality using hand controllers.

For the VR application developed within the project, the consumer virtual reality headset developed by HTC (Vive Pro) has been used. To obtain the interaction within the virtual environment the system uses two optical tracking sensors to monitor the location/orientation of the person wearing the headset.

Within the application created for the Large Round Temple of Sarmizegetusa Regia, the user can walk within the $3 \mathrm{D}$ reconstruction of the temple and interact with multiple 3D artefacts. An image of the virtual reality environment is illustrated in Figure 9.

The current trend is highly influenced by computer games and it involves populating the virtual environments with virtual humans to better showcase the visual appearance of the original inhabitants of the proposed virtual reality environments (Machidon, Duguleana and Carrozzino 2018). Implementing virtual humans represents a complex and challenging task if the desired achieved results are focused on realism and interactivity.

\section{Hand tracking - Leap motion applications}

The Leap Motion sensor represents an interactive tool capable of recognizing hand gestures and movements. The sensor makes use of cameras and infrared

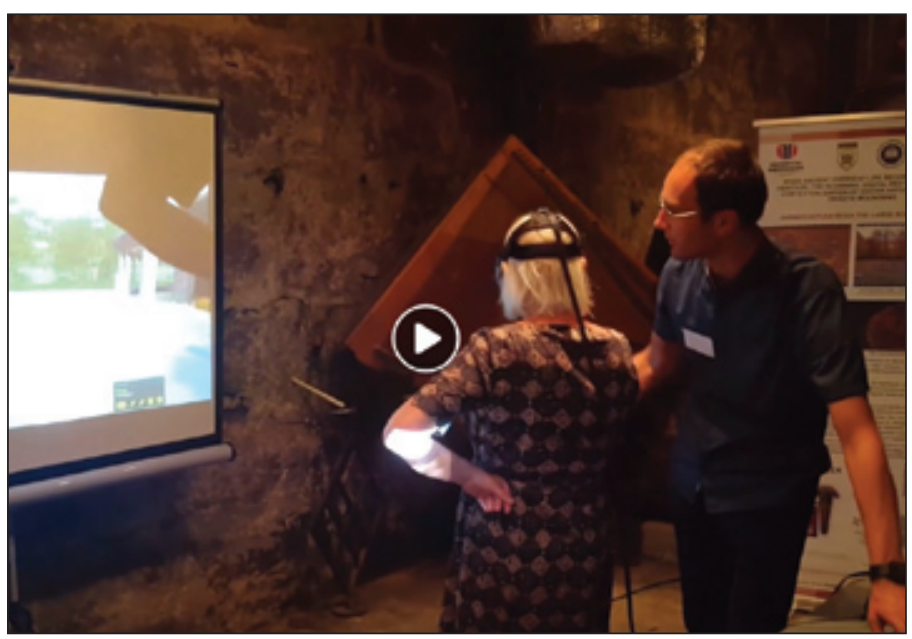

LEDs to track the movements. An indepth analysis of the movement and gesture recognition of the Leap Motion sensor is presented in (Sharma et alii 2018).

Figure 9. The virtual reality environment created for the Large Round Temple from Sarmizegetusa Regia 


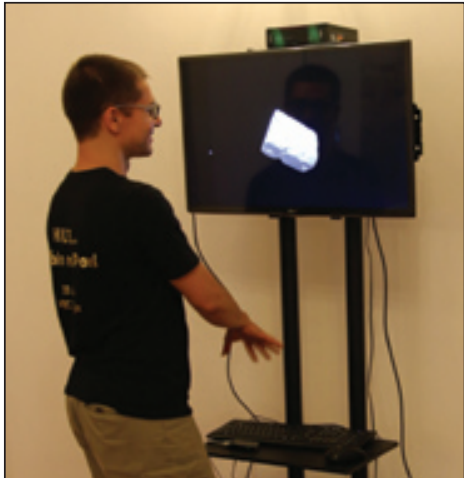

Figure 10. The leap motion application within the Museum of Dacian and Roman Civilisation

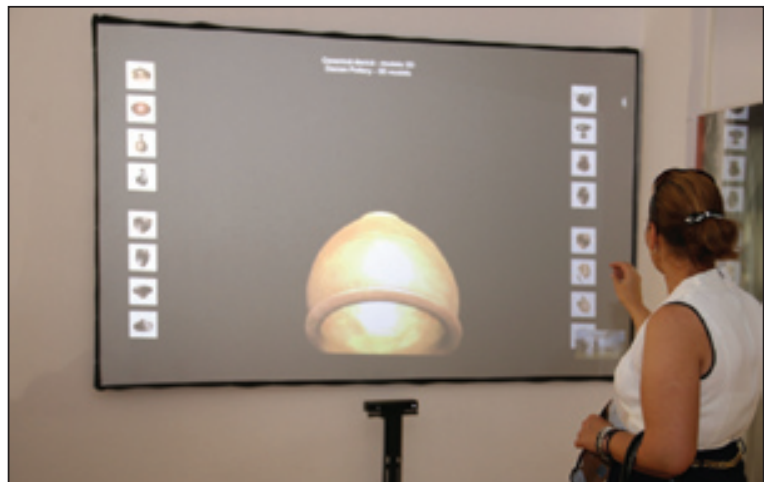

Figure 11. Artefact manipulation using Microsoft Kinect

Within the real-virtual exhibitions, we have integrated two leap motion applications, the only drawback is that the controller needs to be attached to a computer. The computer analyses the camera input data and enables interaction with 3D models using natural gestures.

\section{Body tracking - Kinect V2 applications}

The software application was created using the Leap Motion SDK (available online at developer.leapmotion.com) and with Unity (available online at unity. com). The applications feature multiple 3D scanned artefacts that are being looped every 30 seconds. While the application is in standby mode, the screen is black and only a text that encourages visitors to place your hand over the sensor is displayed. Once the hand is positioned on top of the tracking area the user can control the rotation of the 3D scanned artefact using his hand rotation. One of the applications is presented in Figure 10.

Virtual reality applications that make use of tracking devices have started to be adopted to make cultural heritage exhibitions more enjoyable and engaging for the museum visitors. Natural gestures interaction applications are at the basis of modern digital applications, as the object of the study of many researchers throughout the world.

Full-body tracking applications are capable to approach the mass audience a lot easier since the users can interact with the virtual scene without needing to use controllers or other devices. The leap motion sensor also enables the users to interact without having any devices attached but the tracking area is limited to a small region on top of the sensor, in contrast, the Kinect V2 can track a much wider region (maximum range of about 4.5 meters, compared to 0.6 meters for leap motion) and it can track multiple users in the same time (Figure 11). 


\section{Haptic Device -}

\section{D systems Touch}

A haptic device represents a device that enables users to interact with virtual elements so that they can indirectly feel the physical shapes of digital objects. Haptic devices enable haptic collision detection between the position of the end-effect (usually a stylus pen) and 3D models, they collisions are calculated using computer-processed algorithms to enable real-time tracking and detection. The real-time force/ torque is applied by using the actuators within the haptic device ro make the user to feel the appropriate reaction forces.

The application used within the exhibition makes of multiple 3D scanned vessels

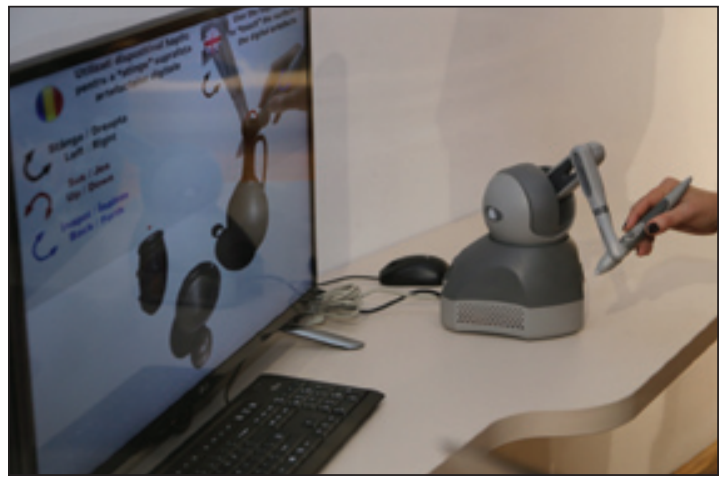

Figure 12. Using haptic device in a museum exhibition

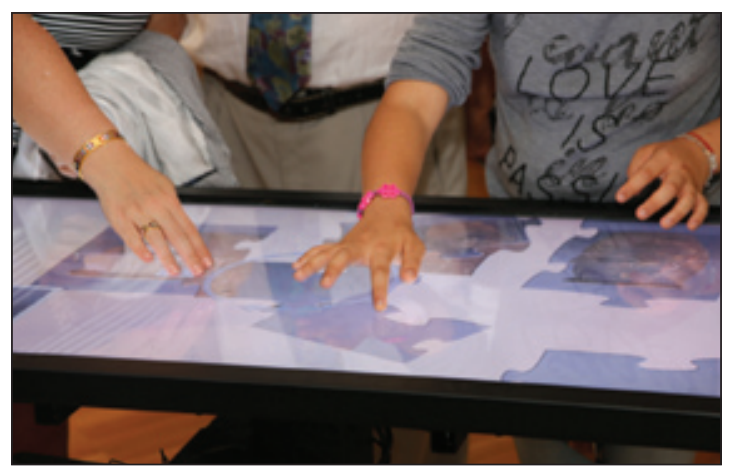

Figure 13. Interactive table that are positioned within the workspace of the haptic device. The user can pick up the vessels and move the virtual probe on the profiles of the scanned vessels (Comes 2016). The virtual probe is represented with a red sphere allowing the user to see the location of the haptic device pointer on the screen.

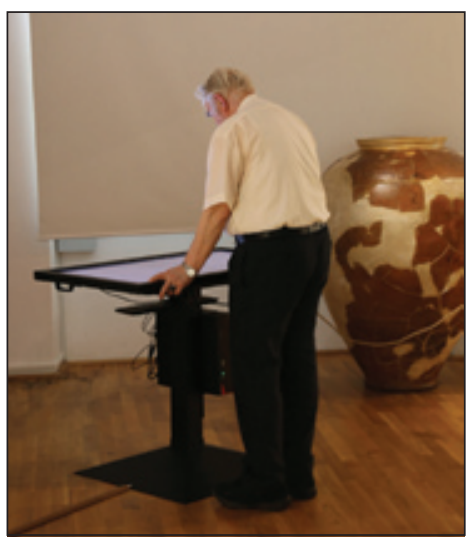

Figure 14. Interactive table

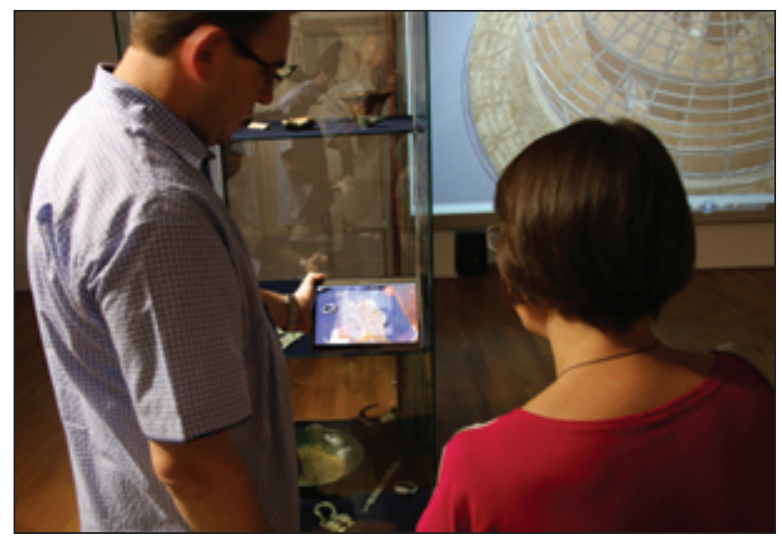

Figure 15. Using Augmented Reality in exhibitions 


\section{Interactive Table - Touchscreen PC}

By using such devices, the public is introduced to a series of images and films in the form of an interactive puzzle, thus aiming at a longer focus of the users and impressing of the information into the memory of the user. Within the exhibitions presenting the heritage of Sarmizegetusa Regia (Figure 13-14) one application and an interactive table allow the users may reconstruct a picture or a film by using several degrees of difficulty or to set up contests in pairs.

\section{Augmented Reality}

The augmented Reality has several opportunities for use with the museum, enriching the visitors' experience (Comes et al. 2014). In the case of the heritage of Sarmizegetusa Regia AR, it is used to present the additional information on the real artefacts exhibited in cases of the visitors. Thus, a spindle weight is exhibited in the case for instance, whilst the application presents a reconstruction of an ancient loom so that the user may understand the context of the use of the exhibited artefact (Figure 15-16).

\section{Conclusions}

Promoting cultural heritage is possible by the use of modern digital techniques that allow dissemination to a large number of users. Virtual and augmented reality are two multimedia technologies that in recent years have developed greatly through the emergence of hardware and software accessible to the broad audience. Promoting the cultural heritage by the use of these two technologies supposes the creation of applications that would allow the users to interact with the digitalized cultural heritage in the "gamification" spirit. The first step in the making of such application types consists of the digitalizing

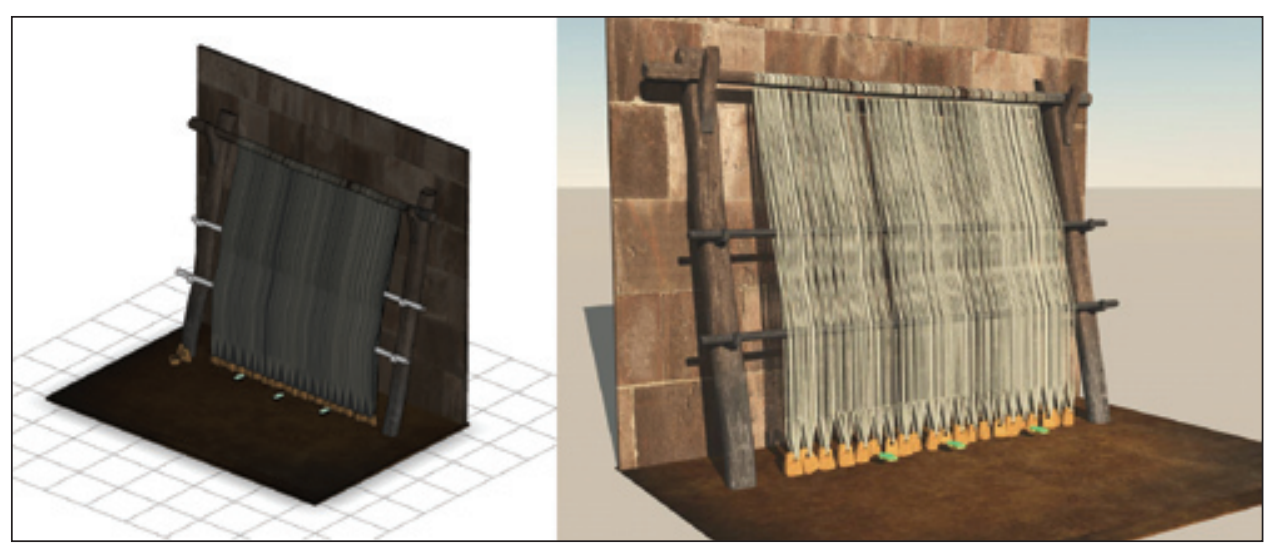

Figure 16. Reconstruction of a loom 


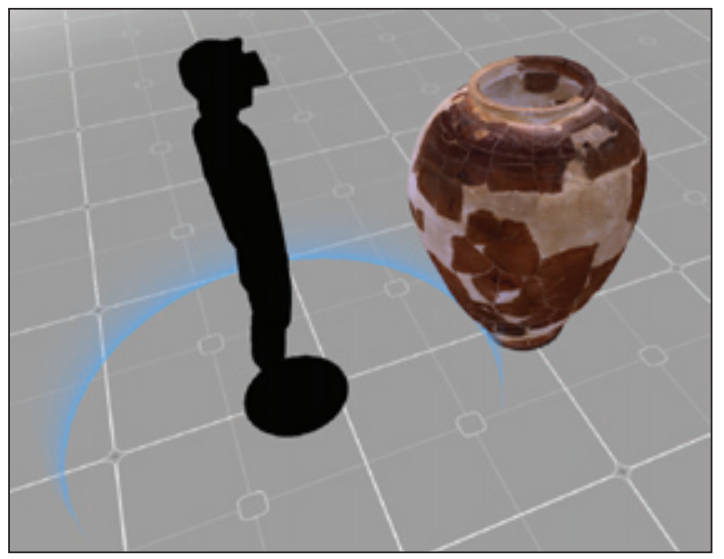

Figure 17. Visualising by Google CardBoard on Sketchfab.com

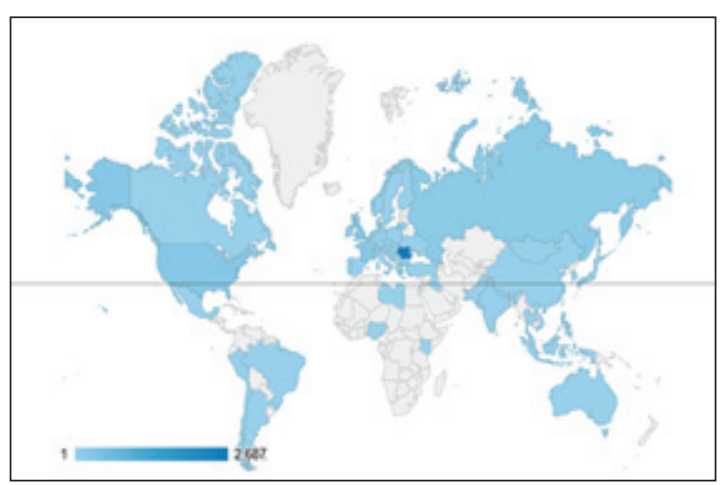

Figure 18. Diffusion of the on-line database users of the heritage objects and monuments. Tocreate a realistic application, the digitalizing must produce truthful digital replicas of the real artefacts and monuments, thus, for such purpose, advanced digitalizing equipment and techniques must be used that would allow the capture of the smallest details of the real monuments and artefacts. In the case of the monuments of Sarmizegetusa Regia, they used terrestrial laser scanners with a scanning accuracy of $1 \mathrm{~mm}$ to $140 \mathrm{~m}$ scanning range for monuments and laser scanners and structured light with an accuracy of $50 \mu \mathrm{m}$ for artefacts. The advantage is the use of virtual reality for promoting the cultural heritage is that monuments or artefacts which can no

longer be reconstructed or restored may be virtually reproduced, added by the possibility of simulating time. The digital restoration of the monuments and artefacts is made by using software and simulating solutions which allow validation in the virtual environment of the proposed solutions. In some cases, after digitalizing and digital restoration there is also a stage of optimizing $3 \mathrm{D}$ models before their use in virtual or augmented reality applications. The interaction of the users with the digitalized artefacts is made by the use of various types of equipment specific to virtual reality and games like tracking sensors, interactive tables, tablets or virtual reality goggles. In the case of the cultural heritage of Sarmizegetusa Regia, digitalized, the users have including the opportunity to use 3D models via the Sketchfab.com platform, where they may be visualized either by Google CardBoard (Figure 17) headsets and the designed application of augmented reality. The dissemination of the digitalized heritage nationally and internationally was made via an on-line 
database and integration to Europeana. To date, according to Google Analytics the on-line database housed on website dacit.utcluj.ro was accessed by users from 63 counties all over the continents (Figure 18). Currently, Romania ranks 7 in the top of 3D models contributors on the Europeana platform with 663 of which 560 are directly related to Sarmizegetusa Regia, namely almost $2 \%$ of the total $3 \mathrm{D}$ objects housed by Europeana ${ }^{19}$. Another aspect to consider in promoting the cultural heritage of Sarmizegetusa Regia was the opportunity to use digitalized models in teaching activities and research. Besides opportunities to visualize and interact with the digitalized models provided through the Sketchfab.com platform, the users download a 3DPDF type file which allows them to measure and examine the digitalized artefacts. Thus, our goal is to transfer historically accurate information to the public.

\section{Acknowledgement}

This research is part of the Project „Preservation by the development of sustainable strategies for better protection of the UNESCO World Heritage Sites from Romania" - archaeoheritage.ro/hero, supported by the National Research Council (CNCS) - Executive Agency for Higher Education, Research, Development and Innovation Funding (UEFISCDI), PN-III-P4-ID-PCE-2016-0737 and implemented under the auspices of the Institute of Archaeology of the Romanian Academy, Iasi Branch, Romania.

\section{References}

Antonescu D. (1984). Introducere în arhitectura dacilor București: Editura Tehnică. Bârcă, V. (2018). "Câteva observații privind administrarea Cetăților dacice din Munții Orăștiei înscrise în lista patrimoniului mondial UNESCO", Plural. HistoryCulture-Society, 6/2: 78-111 (DOI: doi.org/10.37710/plural.v6i2_6).

Bârcă, V. (2019). "Positive and negative aspects in the management of the Dacian Fortresses in the Orăștie Mountains listed among UNESCO world heritage sites," Journal of Ancient History and Archaeology 6/1: 109-148 (DOI: 10.14795/j. v6i1.385).

Bârcă, V. (2019a). "Accomplishments and failures in the management of fortress Sarmizegetusa Regia, a UNESCO World Heritage Monument", Journal of Ancient History and Archaeology, 6/4: 119-150 (DOI:10.14795/j.v6i4.464).

Bodó, C. (2016). "Locuințe” / "Dwellings. In: C. Neamțu, G. Florea, G. Gheorghiu and C. Bodó (eds.), Când viața cotidiană antică devine patrimoniu UNESCO Incursiuni dacice in spațiul virtual, 165-182. Cluj-Napoca: Only One.

${ }^{19}$ The Europeana Foundation is the organisation tasked by the European Commission with developing a digital cultural heritage platform for Europe. 
Bodó, I., V. Ferencz (2004). "Câteva considerații privind fortificația și așezarea dacică de la Ardeu (com. Balșa), jud. Hunedoara”. Istros 9: 147-157.

Carrozzino, M. and M. Bergamasco (2010). "Beyond virtual museums: Experiencing immersive virtual reality in real museums”. Journal of Cultural Heritage 11/4: 452-458.

Ciocca, G., P. Olivo, and R. Schettini (2012). "Browsing museum image collections on a multi-touch table,” Information Systems 37/2: 169-182.

Comes, R. (2016). "Haptic devices and tactile experiences in museum exhibitions". Journal of Ancient History and Archaeology 3/4: 60-64. (DOI: 10.14795/j. v3i4.205)

Comes, R. (2018). "The preservation and long-term use of 3D digitized cultural heritage assets". Acta Electrotehnica 59/3: 267-270.

Comes, R., C. Neamțu, Z. Buna, I. Badiu, and P. Pupeză (2014). "Methodology to create $3 \mathrm{D}$ models for augmented reality applications using scanned point clouds". Mediterranean Archaeology and Archaeometry 14/4: 35-44.

Crișan, I.H. (1986). Spiritualitatea geto-dacilor. Repere istorice. București: Albatros.

Crișan, I.H. (1993). Civilizația geto-dacilor, vol. I. București: Meridiane.

DACIT (2019) = Research Project "When ancient everyday life becomes UNESCO heritage. The scanning, digital restoration and contextualization of Dacian artefacts from Orăştie Mountains”. Online: dacit.utcluj.ro.

Daicoviciu, H, Șt. Ferenczi, I. Glodariu (1989). Cetăți și așezări dacice în sud-vestul Transilvaniei. București: Editura Științifică și Enciclopeică.

Daicoviciu, C. (1954). Cetatea dacică de la Piatra Roșie. București: Editura Academiei Republicii Populare Romîne.

Daicoviciu C. et alii (1955). "Șantierul arheologic Grădiștea Muncelului”. Studii şi Cercetări de Istorie veche 6: 208-209.

Daicoviciu, C. et alii (1961). "Șantierul arheologic Grădiştea Muncelului”. Materiale și cercetări arheologice 7: 309-310.

Florea, G. (1992). “Aspecte ale metalurgiei bronzului în așezările dacice din Munții Orăștiei”. Ephemeris Napocensis 2: 39-47.

Florea, G. (1998). Ceramica pictată. Artă, meșteșug și societate în Dacia preromană (sec. I a. Chr. I p. Chr.). Cluj-Napoca: Presa Universitară Clujeană.

Florea, G. (2011). Dava et oppidum. Débuts de la genes e urbaine en Europe au deuxieme âge du Fer. Cluj-Napoca: Acad. Roumaine, Centre d'Études Transylvaines.

Florea, G. (2017). "Excavations in Sarmizegetusa Regia: Recent Results and Perspectives”. In: F. Mitthof and G. Schörner (eds.), Columna Traiani Traianssäule. Siegesmonument und Kriegsbericht in Bildern. Beiträge der Tagung in Wien anlässlich des 1900. Jahrestages der Einweihung, 9.-12. Mai 2013. Vienna: Verlag Holzhause.

Florea, G. and C. Cristescu (2016). “Artă, identitate și imaginar” / "Art, identity and imaginary”. In: C. Neamțu, G. Florea, G. Gheorghiu and C. Bodó (eds), Când 
viața cotidiană antică devine patrimoniu UNESCO - Incursiuni dacice în spațiul virtua. Cluj-Napoca: Only One.

Florea, G. et alii (2015). Matrița de bronz de la Sarmizegetusa Regia. Cluj-Napoca: Mega. Geller, T. (2006). “Interactive Tabletop Exhibits in Museums and Galleries.”. IEEE Computer Graphics and Applications 26/5: 6-11.

Gimeno, J., C. Portalés, I. Coma, M. Fernández, and B. Martínez (2017). “Combining traditional and indirect augmented reality for indoor crowded environments. A case study on the Casa Batlló museum”. Computers \& Graphics 69: 92-103.

Glodariu, I. (1983). Arhitectua dacilor - civilă și militară (sec. II a. Chr. - I p. Chr.). ClujNapoca: Dacia.

Glodariu, I. (1975). Un atelier de făurărie la Sarmizegetusa dacică. Acta Musei Napocensis 12: 107-134.

Glodariu, I. and E. Iaroslavschi (1979). Civilizația fierului la daci. Cluj-Napoca: Dacia.

Glodariu, I. and V. Moga (1989). Cetatea dacică de la Căpâlna. București: Editura Științifică și Enciclopedică.

Glodariu, I., E. Iaroslavsch and A. Rusu (1988). Cetăți şi aşezări dacice în Munții Orăştiei. București: Sport-Tourism.

Glodariu, I., E. Iaroslavschi and A. Rusu (1992). "Die Münzstatte von Sarmizegetusa Regia”. Ephemeris Napocensis 2: 57-68.

Gheorghiu, G. (1996). “Cisterna dacică de la Grădiştea de Munte”. Acta Musei Napocensis 33/1: 375-384.

Gheorghiu, G. (1997-1998). “Cisterne descoperite în zona capitalei regatului dac”. Sargetia 27/1: 177-189.

Gheorghiu, G. (2005). Dacii pe cursul mijlociu al Mureșului (sfârșitul sec. II a. Chr. inceputul sec. II p. Chr.). Cluj-Napoca: Mega.

Gheorghiu, G. and P. Pupeză (2016). ”Instalații de stocare și de distribuire a apei” / "Water storage and supply installations”. In: C. Neamțu, G. Florea, G. Gheorghiu and C. Bodó (eds), Când viața cotidiană antică devine patrimoniu UNESCO Incursiuni dacice în spațiul virtual, 183-192. Cluj-Napoca: Only One.

He, Z., L. Wu and X.R. Li (2018). "When art meets tech: The role of augmented reality in enhancing museum experiences and purchase intentions”. Tourism Management 68: 127-139.

Hornecker, E. (2008). “"I don't understand it either, but it is cool” - visitor interactions with a multi-touch table in a museum”. In: $3^{\text {rd }}$ IEEE International Workshop on Horizontal Interactive Human Computer Systems, 113-120. Amsterdam: 2008.

Iaroslavschi, E. (1981). “Au prelucrat dacii sticla?”. In: E. Daicoviciu (ed.), Studii dacice, 166-173. Cluj-Napoca: Dacia.

Iaroslavschi, E. (1997). Tehnica la daci. Cluj-Napoca: Muzeul Național de Istorie a Transilvaniei.

Iaroslavschi, E. (2004). “Zona siderurgică din preajma capitalei statului dac”. In: A. Pescaru and I.V. Ferencz (eds), Daco-Geții, 58-59. Deva: Muzeul Civilizației Dacice şi Romane. 
Iaroslavshi, E. and R. Mateescu (2016). "Meșteșuguri” / "Crafts”. In: C. Neamțu, G. Florea, G. Gheorghiu, and C. Bodó (eds), Când viața cotidiană antică devine patrimoniu UNESCO - Incursiuni dacice în spațiul virtual, 63-66. Cluj-Napoca: Only One.

Keil, J. et alii (2013). "A digital look at physical museum exhibits: Designing personalized stories with handheld Augmented Reality in museums". In: Proceedings of the Digital Heritage, vol. 2, 685-688. Marseille.

Kyriakou, P. and S. Hermon (2019). "Can I touch this? Using Natural Interaction in a Museum Augmented Reality System”. Digital Applications in Archaeology and Cultural Heritage 12, e00088.

Neamțu, C., R. Comes and D. Popescu (2016). "Methodology to create digital and virtual 3D artefacts in archaeology". Journal of Ancient History and Archaeology 3/4 (DOI: 10.14795/j.v3i4.206).

Neamțu, C., Florea, G. Gheorghiu, and C. Bodó (eds.) (2016). Când viața cotidiană antică devine patrimoniu UNESCO - Incursiuni dacice în spațiul virtual. ClujNapoca: Only One.

Machidon, O.M., M. Duguleana and M. Carrozzino (2018). "Virtual humans in cultural heritage ICT applications: A review”. Journal of Cultural Heritage 33: 249-260.

Mateescu, R. (2010). "Între aducere de ofrandă şi ascundere. Studiu de caz asupra depunerii brățărilor dacice de aur” In: I. Glodariu and G. Gheorghiu (eds), Studii de Istorie şi Arheologie. Omagiu cercetătorului dr. Eugen Iaroslavschi, 128-140. ClujNapoca: Argonaut.

Mateescu, R. (2012). Istoriile unui templu. Cluj-Napoca: Mega.

Mateescu, R. (2016). "Arhitectura religioasă” / "Religious Architecture”. In: C. Neamțu, G. Florea, G. Gheorghiu, and C. Bodó (eds), Când viața cotidiană antică devine patrimoniu UNESCO - Incursiuni dacice în spațiul virtual, 95. Cluj-Napoca: Only One.

Mateescu, R. (2017). "Digging and Excavating at Sarmizegetusa Regia in the 19th and 20th Century”. In: F. Mitthof and G. Schörner (eds), Columna Traiani Traianssäule. Siegesmonument und Kriegsbericht in Bildern. Beiträge der Tagung in Wien anlässlich des 1900. Jahrestages der Einweihung, 9.-12. Mai 2013 [TYCHE Sonderband 9], 357-362. Viena: Verlag Holzhausen.

Mateescu, R. and P. Pupeză (2016). "Elemente de arhitectura militară” / Aspects of the military architecture”. In: C. Neamțu, G. Florea, G. Gheorghiu, and C. Bodó (eds), Când viața cotidiană antică devine patrimoniu UNESCO - Incursiuni dacice în spațiul virtual, 221-249. Cluj-Napoca: Only One.

Moga, V. (1979). "Piese de argint din cetatea dacică de la Piatra Craivii”. Acta Musei Napocensis 16: 513-518.

Moga, V. and A. Rustoiu (1997). "Atelierul de fibule de la Piatra Craivii (jud. Alba)". Ephemeris Napocensis 7: 57-63. 
Rey, F.B. and D. Casado-Neira (2013). "Participation and Technology: Perception and Public Expectations about the Use of ICTs in Museums". Procedia Technology 9: 697-704.

Rustoiu A. (1996). Metalurgia bronzului la daci (sec. II î. Chr. - sec. I d. Chr.). Tehnici, ateliere şi produse din bronz. București: Vavila Edinf.

Rusu-Pescaru, A. (2005). Sanctuarele Daciei. Deva.

Sharma, A., A. Yadav, S. Srivastava and R. Gupta (2018). «Analysis of movement and gesture recognition using Leap Motion Controller». Procedia computer science 132: 551-556.

Suciu, L. (2000). “Organizarea și amenajarea spațiului în locuințele așezării civile de la Grădiștea de Munte”. Revista Bistriței 14: 36-47.

UNESCO (1999) = UNESCO World Heritage Centre. World Heritage List - Dacian Fortresses of the Orastie Mountains. Online: whc.unesco.org/en/list/906.

Vi, C.T., D. Ablart, E. Gatti, C. Velasco, and M. Obrist (2017). "Not just seeing, but also feeling art: Mid-air haptic experiences integrated in a multisensory art exhibition.”. International Journal of Human-Computer Studies 108: 1-14.

VRS (2017) = Virtual Reality Society. What is Virtual Reality. Online: www.vrs.org.uk/ virtual-reality/what-is-virtual-reality.html.

\section{Promovarea și valorificarea vestigiilor de la Sarmizegetusa Regia prin metode multimedia moderne}

\section{Rezumat}

Sarmizegetusa Regia a fost inclusă, împreună cu alte cinci cetăți dacice (Bănița, Costești-Blidaru, Costești-Cetățuie, Piatra Roșie și Căpâlna), pe Lista Patrimoniului Mondial UNESCO în 1999. Ele reprezintă o sinteză unică a influențelor culturale externe și a tradițiilor locale în ceea ce privește tehnicile de construcție și, în general, în arhitectura militară antică, reprezentând marea expresie a civilizației Regatului dac. Sarmizegetusa Regia, situându-se în fruntea acestui complex fortificat, reprezintă fenomenul evoluției de la centrele fortificate până la aglomerările protourbane. Promovarea acestor monumente și a numeroaselor artefacte descoperite prin metode și tehnici moderne ar trebui să devină o prioritate a activităților de cercetare și valorificare a patrimoniului arheologic. Această lucrare prezintă o serie de aplicații și echipamente de ultimă generație care pot fi utilizate cu succes în promovarea patrimoniului cultural. Studiile de caz includ artefacte scanate și reconstrucții 3D ale monumentelor din situl Sarmizegetusa Regia. Prezentăm aici rezultatele obținute în urma utilizării mai multor sisteme de urmărire hardware, aplicaţii de realitate virtuală augmentată și dispozitive haptice. Unul dintre aspectele importante, atunci când se încearcă îmbunătățirea utilizării on-line a pa- 
trimoniului este măsura în care acesta este accesibil și reutilizabil de către diverse categorii de utilizatori, fie specialiști, fie publicul larg. Digitalizarea unui bun în patrimoniul cultural este primul pas pentru asigurarea accesului larg prin intermediul suportului on-line, calitatea acestui proces asigurând legitimitatea și credibilitatea artefactului formatului electronic. În acest fel, ele pot fi păstrate digital și utilizate în diferite maniere. Digitalizarea artefactelor și reconstrucția digitală a caselor, accesoriilor, atelierelor, templelor și fortificațiilor și amenajarea tururilor virtuale asigură incursiuni în viața de zi cu zi, rezultate din descoperirile arheologice realizate de-a lungul mai multor decenii. Acest proces are ca rezultat promovarea rapidă a acestui patrimoniu cultural și valorificarea sa internațională.

Cuvinte cheie: Sarmizegetusa Regia, digitalizarea patrimoniului cultural, scanarea laser terestră, realitate virtuală, baza de date on-line, diseminarea patrimoniului cultural

Călin Neamțu, Technical University of Cluj-Napoca, e-mail: calin.neamtu@muri.utcluj.ro

Vitalie Bârcă, Institute of Archaeology and Art History fromInstitute of Archaeology and Art History of Cluj-Napoca, Cluj-Napoca e-mail: vitalie_barca@yahoo.com

Zsolt Buna, Technical University of Cluj-Napoca, e-mail:zsolt.buna@mail.utcluj.ro 